\title{
Establishing A Certified Financial Plannerтм Program At A Regional University
}

Stephen J. Larson, (Email: sjlarson@eiu.edu )Minnesota State University, Mankato William B. Joyce, Eastern Illinois University

David McGrady, Eastern Illinois University

\begin{abstract}
This paper discusses the process of establishing a Certified Financial Planner ${ }^{\mathrm{TM}}$ program at a regional state university as well as the benefits of such a practical program for students. In 2003 the financial planning curriculum at Eastern Illinois University became board registered by the Certified Financial Planner ${ }^{\mathrm{TM}}$ Board. Students take five courses covering taxation, insurance, investments, retirement planning, and estate planning. This curriculum satisfies the requirements to sit for the Certified Financial Planner ${ }^{\mathrm{TM}}[C F P 囚]$ exam. Recent students of our program have obtained good jobs primarily in the area of retirement planning and investments.
\end{abstract}

\section{INTRODUCTION}

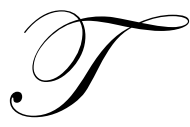

he convergence of financial services is an important emerging trend for finance students to consider. A single financial institution now sells a variety of financial products whereas years ago each financial institution specialized in only certain products. For example, State Farm Insurance agents formerly sold and serviced only insurance products such as automobile insurance, homeowners insurance, life insurance, and health insurance. Today, in addition to insurance, State Farm Insurance agents can sell investment products, retirement products, and they can even offer banking services. Today's financial services representative is expected to be well versed in a broad array of financial services. Thus, finance students wanting a career selling and servicing personal financial products will benefit if they obtain broad knowledge in the financial services area.

The Certified Financial Planner ${ }^{\mathrm{TM}}$ [CFP $\left.{ }^{\circledR}\right]$ designation signifies a person has successfully passed a two-day examination offered by the Certified Financial Planner ${ }^{\mathrm{TM}}$ Board. This ten-hour exam covers seven areas of personal financial planning. The section on the General Principles of Financial Planning includes personal budgeting, funding your child's college education, amortized loans, and types of property. The area on Insurance Planning and Risk Management includes details on what is covered by various policies, insurance policy selection, legal aspects of insurance, and the taxation of insurance policy benefits. Employee Benefits Planning covers employee benefit plans, employee stock options, and deferred compensation plans. The Investment Planning section includes the types of investment vehicles (e.g. stocks, bonds, options), measuring investment risk, investment strategies, and the taxation of investment vehicles. In Income Tax Planning the topics include calculating income tax liability, the alternative minimum tax, charitable contributions, and the income taxation of trusts and estates. The section on Retirement Planning covers Social Security, Medicare, the many types of retirement plans, and the taxation of retirement income. Finally, the area on Estate Planning includes methods of transferring property at death (e.g. wills and trusts), gifting strategies, powers of appointment, and the liquidity needs of an estate.

In order to sit for the CFP® exam students must take courses that are registered with the Certified Financial Planner ${ }^{\mathrm{TM}}$ Board. These courses can be part of a finance curriculum for undergraduate or graduate students enabling them to not only obtain enough credits for graduation, but also to sit for the CFP® examination. Upon graduation, such students should be well versed in the area of financial planning and ready for a career in the financial services industry. 


\section{AT EASTERN HOW DO STUDENTS BENEFIT?}

Illinois University we find our successful students obtain good jobs in the area of retirement planning and investments. Almost all of our students do not take the CFP® examination right after graduating our program. The review course and exam fees cost about $\$ 2,000$ so our students tell us they plan to work for a while hoping their firms will reimburse these expenses. We strongly encourage our students to take a review course because such courses greatly enhance the pass ratio. These courses enable the students to review the details of each area and to see better how the separate areas of financial planning are related. We plan to offer a review course to our students each year.

In Les Krantz's book, Jobs Rated Almanac ( $5^{\text {th }}$ edition), 250 jobs are ranked according to income (entry level and beyond), environment (work week and confinement), outlook (growth of industry), physical demands, security (unemployment rate and physical security), and job perks. According to Mr. Krantz's research, financial planner is the number one profession.

A 2005 study by the College for Financial Planning conducted a survey after polling 419 CFP® certificate holders. The median gross annual earnings of CFP certificate holders was $\$ 277,800$ in 2005 . In 2004 the median annual earnings was only $\$ 219,000$. Young financial planners also report that their income increased from $\$ 87,700$ to $\$ 107,400$ after securing the CFP® designation. The study also reports that planners are aging, as nearly three-fourths of them are over forty years old; this is good news for financial planning students. The results of this study also suggest CFP®'s are quite content with their jobs even when not considering compensation.

Starting in 2007 a person must have a bachelor's degree in order to sit for the CFP ${ }$ examination. This is good for college students studying financial planning since they are getting undergraduate degrees anyway.

\section{HOW A FINANCIAL PLANNING PROGRAM CAN BECOME BOARD CERTIFIED?}

We initially became interested in offering the CFP® curriculum after discussions with our School of Business Advisory Board. At that time, State Farm Insurance, Merrill Lynch, and Price Waterhouse were adding financial planning to the services they offered. To sit for the CFP® exam one must complete the curriculum at a university approved program or qualify for challenge status (attorney, CPA, Ph.D.). At the time of our application we needed to show how we would cover the 101 topics outlined by the CFP® Board. This list is currently being revised down to eighty-nine topics.

Our July 2003 application is contained in a two and one-half inch binder and it took quite a bit of time to pull together. We had to show how the CFP® curriculum would fit into our finance major. Our students take five courses: Investments, Risk and Insurance, Fundamentals of Financial and Tax Planning, Retirement and Estate Planning, and Portfolio Management. With two courses in investments our students become quite strong in this area. However, we are currently analyzing our program to determine if we should offer Retirement Planning and Estate Planning in separate courses. A problem we encounter is that we don't want our students to be required to take more than 120 credits to graduate our program. In our application, we show just where each of the 101 topics is covered; each course syllabus is included. It took some time to coordinate the professors' syllabi to be sure we adequately cover each topic and to minimize redundancy.

Our business program policies are included along with a course description for each course finance majors take. A description of our library resources is also included along with the School of Business Mission Statement and Strategic Plan. The most important element of the application is to show how the 101 topics are covered in the courses a student takes for her or his financial planning concentration. You can access the CFP® Board at www.cfpboard.net.

\section{ASSESSMENT ISSUES AND THE CFP® EXAM}

Accrediting bodies such as AACSB are quite interested in assessment. They want to ascertain that students are actually learning. These bodies are looking for evidence of learning over and above passing exams given by 
their instructors. The CFP® Exam can help or hurt a school in this area depending on how well financial planning graduates do on this examination. Program pass rates are available and these can be compared to average pass rates. For instance, the average pass rate for the November 2005 exam may be 55\%, yet $68 \%$ of $\mathrm{XYZ}$ Business School graduates passed. The use of CFP® pass rates as an assessment tool is clearly a doubleedged sword as your graduates may do better or worse than average. We recommend students be required to take a required mock CFP® exam at the end of their coursework. This will enable the Program Coordinator to assess program strengths and weaknesses in specific areas and take corrective action. For instance, students may do very well in all areas except retirement planning. This type of feedback loop is quite appealing to assessment proponents.

\section{CURRENT ISSUES WITH OUR PROGRAM}

Having a structured program is very appealing to students and even to some advisors. When students choose the CFP® concentration they do not have to pick and choose from the list of finance electives. We find that most of our finance majors choose the financial planning concentration and thus do not sign up for other courses taught by our colleagues. Specifically, courses in real estate, international finance, and applied portfolio investing have suffered from reduced enrollment.

When asked many of our financial planning students say they have no intention of sitting for the exam or even entering the field of financial planning. This leaves us wondering why they choose the CFP® curriculum. We are in the process of creating ways to direct uninterested students in to our other finance electives. Before a student declares his or her intent to take the financial planning concentration we interview him or her. In these interviews some students demonstrate limited insight into what a financial planner actually does, so we try to persuade them to take advantage of our other electives.

Currently the CFP® Board is suggesting we may better suit students by offering retirement planning and estate planning in separate courses. We agree that there is a great deal of material in these two areas and that two courses would perhaps be better. A problem we have, however, is that we do not want exceed 120 credit hours as this would be very problematic for our administrators and curriculum committee. It is not appealing to have a bachelor's degree exceed 120 credit hours. In order to improve our program we are considering only offering one course in Investments allowing us to offer Retirement Planning and Estate Planning separately.

Finally, we are stressing to our students to take our review course or even another review course if that is more convenient. Many of our students are from the Chicago area where review courses are offered in the summer. It is common knowledge that the chance of failure is quite high without a review course. A potential problem is that our program's pass rate will be compared to the national average; there are many certificate programs where established financial planners are taking $C F P \circledast$ courses anticipating taking the $\mathrm{CFP} \circledast$ exam.

\section{CONCLUSION}

Overall we are quite satisfied with our decision to offer the CFP® curriculum at Eastern Illinois University. We find that our successful students obtain decent jobs especially in the area of retirement planning and investments. Employers seem interested in students who have just taken the CFP® courses even though they have not yet sat for the examination.

\section{REFERENCES}

1. Hersch, Warren S., Study Reveals Rising Pay, Satisfaction Among CFP Certificants, September 26, 2005, National Underwriter Life and Health.

2. $\quad$ Krantz, Les, Jobs Rated Almanac, (5 ${ }^{\text {th }}$ edition), 2001, St. Martin's Press.

3. Rejda, George E., Principles of Risk Management and Insurance, (ninth edition), 2005, Addison Wesley. 


\section{NOTES}

